\title{
Trafficking of phagocytic peritoneal cells in hypoinsulinemic-hyperglycemic mice with systemic candidiasis
}

\author{
Thais Fernanda de Campos Fraga-Silva ${ }^{1,2}$, James Venturini ${ }^{1,3}$ and Maria Sueli Parreira de Arruda ${ }^{1 *}$
}

\begin{abstract}
Background: Candidemia is a severe fungal infection that primarily affects hospitalized and/or immunocompromised patients. Mononuclear phagocytes have been recognized as pivotal immune cells which act in the recognition of pathogens, phagocytosis, inflammation, polarization of adaptive immune response and tissue repair. Experimental studies have showed that the systemic candidiasis could be controlled by activated peritoneal macrophages. However, the mechanism to explain how these cells act in distant tissue during a systemic fungal infection is still to be elucidated. In the present study we investigate the in vivo trafficking of phagocytic peritoneal cells into infected organs in hypoinsulinemic-hyperglycemic $(\mathrm{HH})$ mice with systemic candidiasis.
\end{abstract}

Methods: The red fluorescent vital dye PKH-26 PCL was injected into the peritoneal cavity of Swiss mice 24 hours before the intravenous inoculation with Candida albicans. After 24 and 48 hours and 7 days of infection, samples of the spleen, liver, kidneys, brain and lungs were submitted to the microbiological evaluation as well as to phagocytic peritoneal cell trafficking analyses by fluorescence microscopy.

Results: In the present study, $\mathrm{PKH}^{+}$cells were observed in the peritoneum, kidney, spleen and liver samples from all groups. In infected mice, we also found $\mathrm{PKH}^{+}$cells in the lung and brain. The $\mathrm{HH}$ condition did not affect this process.

Conclusions: In the present study we have observed that peritoneal phagocytes migrate to tissues infected by C. albicans and the $\mathrm{HH}$ condition did not interfere in this process.

\section{Background}

Systemic fungal infections in general, and of candidemia in particular, are severe infections that frequently affect immunocompromised patients including the patients with diabetes mellitus (DM) which correspond to $13 \%-21 \%$ of all candidemia episodes [1-3]. Experimental studies have shown that DM condition increases the susceptibility to candidiasis [4-6]; however, the immunological mechanisms involved in this process have not been extensively studied.

Deficiency in the host immune system is the major predisposing factor to Candida spp infection [7-9]. Macrophages are pivotal immune cells which act in the

\footnotetext{
*Correspondence: sueli@fc.unesp.br

${ }^{1}$ Faculdade de Ciências, Bauru, Departamento de Ciências Biológicas, Laboratório de Imunopatologia Experimental (LIPE), UNESP - Univ Estadual Paulista, Bauru, SP 17033-360, Brazil

Full list of author information is available at the end of the article
}

recognition of pathogens, phagocytosis, inflammation, polarization of adaptive immune response and tissue repair. They are deeply involved in the control and/or eradication of Candida infections [10,11].

Conchon-Costa et al. [12] demonstrated the possibility of controlling systemic candidiasis by activated peritoneal macrophages in the experimental model of Concanavalin A (ConA)-treated mice, using intraperitoneal route during systemic candidiasis. The researchers observed a decrease of the mortality of treated-mice challenged with a lethal dose of Candida albicans. This event was associated with increased TNF- $\alpha$ production, mannose receptor expression and candidacidal activity by peritoneal cells $[12,13]$.

The participation of activated peritoneal cells in distant infections and/or inflammation has been suggested for some time. The migration of cells between the peritoneal cavity and inflamed [14-17], infected [16], neoplastic [18] and adipose tissues [19] have been demonstrated. Considering

\section{Biomed Central}


that the peritoneal cavity serves as an alternative site for immunotherapeutic procedures, the present study investigates the possibility that peritoneal phagocytes migrate to tissues infected by fungi. Because fungal infections are more frequent and difficult to remission in patients with DM, we also investigated the possibility that the hypoinsulinemic-hyperglycemic $(\mathrm{HH})$ condition affects the peritoneal cell trafficking. According to our knowledge, this is the first study to explore migrating peritoneal phagocytes during systemic candidiasis.

\section{Methods}

Mice

Forty-five-day old male Swiss and C57Bl/6 mice from the Animal House of the Laboratório de Imunopatologia Experimental (LIPE), Departamento de Ciências Biológicas, Faculdade de Ciências, UNESP - Univ Estadual Paulista were used for the experiments. The animals received balanced diet and water ad libitum. All procedures were performed in accordance to the ethical standards established by the Brazilian College of Animal Experimentation (Colégio Brasileiro de Experimentação Animal COBEA) and approved by the Committee for Ethics in Animal Experimentation of the Faculdade de Ciências UNESP/Bauru.

\section{Fungi}

C. albicans strain FCF 14 was originally obtained from the mycology collection of the Faculdade de Odontologia de Guaratinguetá, UNESP - Univ Estadual Paulista and was maintained in our mycological collections on Sabouraud dextrose agar (Difco Laboratories, Detroit, Michigan, USA) and monthly samplings in Sabourauddextrose medium.

\section{Experimental design}

Sixty Swiss mice were distributed into 4 groups: Group $\mathrm{Ca}$, which was composed of $18 \mathrm{C}$. albicans-infected mice; Group $\mathrm{HH}-\mathrm{Ca}$, composed of $18 \mathrm{HH}$-induced and C. albicans-infected mice; Group HH, composed of 18 $\mathrm{HH}$-induced mice; and Control Group (CTL), composed of 6 free $\mathrm{HH}$-induced and non-infected mice which were subjected to the same inoculation procedures using sterile saline solution (SSS).

\section{Induction of the $\mathrm{HH}$ condition}

Alloxan administration in laboratory animals selectively destroys the insulin-producing pancreatic $\beta$-cells [20]. Mice were intravenously inoculated by alloxan (Sigma Chemical Co., St. Louis, MO, USA) in a single dose of 60 $\mathrm{mg} \mathrm{kg}^{-1}$ of body weight into the caudal vein. Hyperglycemia was confirmed 48 hours (h) later using Accu-Check Advantage II blood glucose test strips (Roche, Mannheim, Germany). Only mice showing blood glucose levels
$200 \mathrm{mg} \mathrm{dl}^{-1}$ were considered $\mathrm{HH}$ and included in the experiment. The glucose levels during the experiment were typically $400-600 \mathrm{mg} \mathrm{dl}^{-1}$ in $\mathrm{HH}$ mice. Control mice (Ca and CTL groups) were treated identically with a sterile saline solution and presented serum glucose levels ranging from 90 to $130 \mathrm{mg} \mathrm{dl}^{-1}$.

\section{Induction of systemic candidiasis}

The C. albicans inoculum was obtained from a fungal suspension as previously described [21]. The fungal concentration was adjusted to $5.0 \times 10^{7}$ viable $C$. albicans $\mathrm{ml}^{-1}$. The C. albicans suspension has been inoculated into the lateral tail vein. Mice of the $\mathrm{Ca}$ and $\mathrm{HH}-\mathrm{Ca}$ groups were inoculated with $0.1 \mathrm{ml}$ of this suspension and, in the HH-Ca groups the mice were inoculated two days after $\mathrm{HH}$ induction. Tests previously performed in our lab demonstrated that this inoculums size is not lethal in naïve Swiss mice and it reproduces a systemic fungal infection (data not shown).

\section{Determination of peritoneal cellular trafficking Direct injection of PKH-26 PCL into the peritoneal cavity} Peritoneal phagocytes were labeled with the fluorescent vital dye PKH-26 PCL in accordance with the manufacturer's protocol (Sigma). Briefly, $2.0 \times 10^{-6} \mathrm{M}$ PKH-26 PCL was diluted in the diluents $\mathrm{B}$ and $24 \mathrm{~h}$ before to the fungal inoculation, $0.1 \mathrm{ml}$ of the PKH-26 PCL use solution was injected into the peritoneal cavity of each mouse.

\section{Adoptive cell transfer assay}

In order to confirm the peritoneal cells migration, we have used the adoptive cell transfer assay. As the Swiss mice are outbred strain, we have employed C57BL/6 inbred mice to perform the experiments as cell donor and recipient mice. A peritoneal lavage (PL) was performed in the donor mice, and the harvested cells were stained with $\mathrm{PKH}-26$ PCL using the protocol according the previous item. After 30 minutes, the samples were centrifuged at $1500 \mathrm{rpm}$ for 5 minutes and washed extensively with cold and sterile phosphate buffered saline (PBS). Naïve recipient mice were then intraperitoneally inoculated with $2 \times 10^{6} \mathrm{PKH}^{+}$cells. After $24 \mathrm{~h}$, these mice were intravenously challenged with $5 \times 10^{6} \mathrm{C}$. albicans and subsequently analyzed $24 \mathrm{~h}, 48 \mathrm{~h}$ and 7 days after the fungal inoculation.

\section{Collection of biological samples}

The mice were euthanized by carbon dioxide inhalation $\left(\mathrm{CO}_{2}\right) 24 \mathrm{~h}, 48 \mathrm{~h}$ or 7 days after the fungal inoculation. PL was performed with cold and sterile PBS. To confirm the presence of $\mathrm{PKH}^{+}$cells in the PL samples, smears were prepared with $0.1 \mathrm{ml}$ of the sample. Spleen, brain, liver, lung and kidney samples were also collected from the euthanized mice. 


\section{Imprint}

Using a scalpel, vertical sections were made on the tissues selected for the study. The pieces were pressed against glass slides and allowed to dry at room temperature. After washing them with PBS, the imprinted slides were mounted using Fluoroshield ${ }^{\mathrm{TM}}$ with DAPI (Sigma). The slides were analyzed with a fluorescence microscope (BX61, Olympus Optical, Tokyo, Japan). Following the identification of the migrating cells, the slides were subjected to confocal laser scanning microscopy analysis (TCS-SPE, Leica Microsystems, Mannheim, Germany), and images were captured using Leica LAS-AF Software.

\section{Determination of fungal load}

The spleen, brain, liver, lung, kidney and PL samples were submitted to microbiological evaluation in order to determine the fungal load. After collection, the samples were weighed and macerated in $1.0 \mathrm{ml}$ of sterile PBS. A volume of $0.1 \mathrm{ml}$ was spread over culture plates containing Sabouraud-dextrose agar using a Drigalski T loop. The procedures were performed in duplicate. The plates were then sealed and incubated at $37^{\circ} \mathrm{C}$ for 3 days. The number of colony forming units (CFU) was normalized per gram of tissue.

\section{Statistical analyses}

Statistical tests were performed using SigmaPlot Software version 12.0 for Windows (1995, Jandel Corporation, San Rafael, CA, USA), and the significance level established to verify the null hypothesis was $5.0 \%$. The data passed in normality test (Shapiro-Wilk) and the comparison of two independent samples was analyzed using a $t$ test [22].

\section{Results}

\section{$\mathrm{HH}$ condition leads to an increase of fungal load}

The intravenous inoculation of $C$. albicans resulted in acute systemic dissemination affecting the kidney, spleen, liver, lung and brain. The $\mathrm{HH}$ condition did not affect the distribution of the fungi at $24 \mathrm{~h}$ and $48 \mathrm{~h}$. However, on day 7, the mice of $\mathrm{HH}-\mathrm{Ca}$ group exhibited higher fungal load in the liver than Ca group (Figure 1).

\section{Systemic infection by $C$. albicans enhances the spreading} of labeled peritoneal phagocyte to infected tissue

Several methods have been used to determine cell trafficking such as adoptive cell transfer [14-16], ex vivo assays [19], cryogenic tissue evaluation [18,19] and flow cytometry $[14,17,19,23]$. In the preset study we used the PKH-26 PCL as tracing cell marker and imprinting technique to evaluate the migration of labeled cells. The vital fluorescent dye PKH-26 PCL provides strong fluorescence without causing functional damage to the cell. This dye induces the formation of aggregates, which allows the identification of phagocytic cells, such as
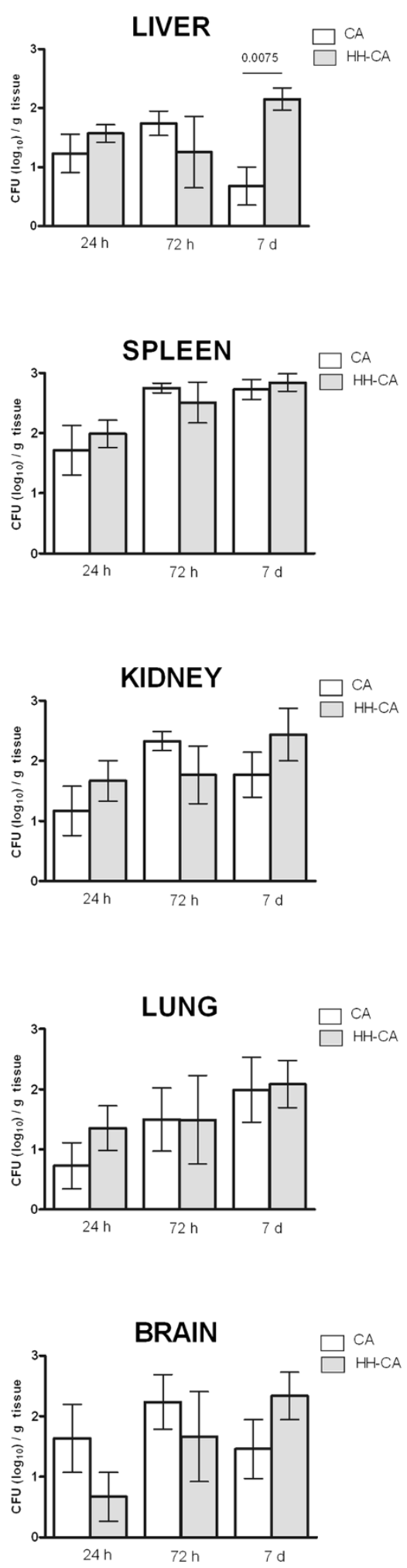

Figure 1 Determination of fungal load in the $\mathrm{Ca}$ and $\mathrm{HH}-\mathrm{Ca}$ groups. The results are expressed as CFU $\left(\log _{10}\right)$ per gram of tissue ( $t$ test; $p<0.05 ; n=6 /$ group and experimental moment). 


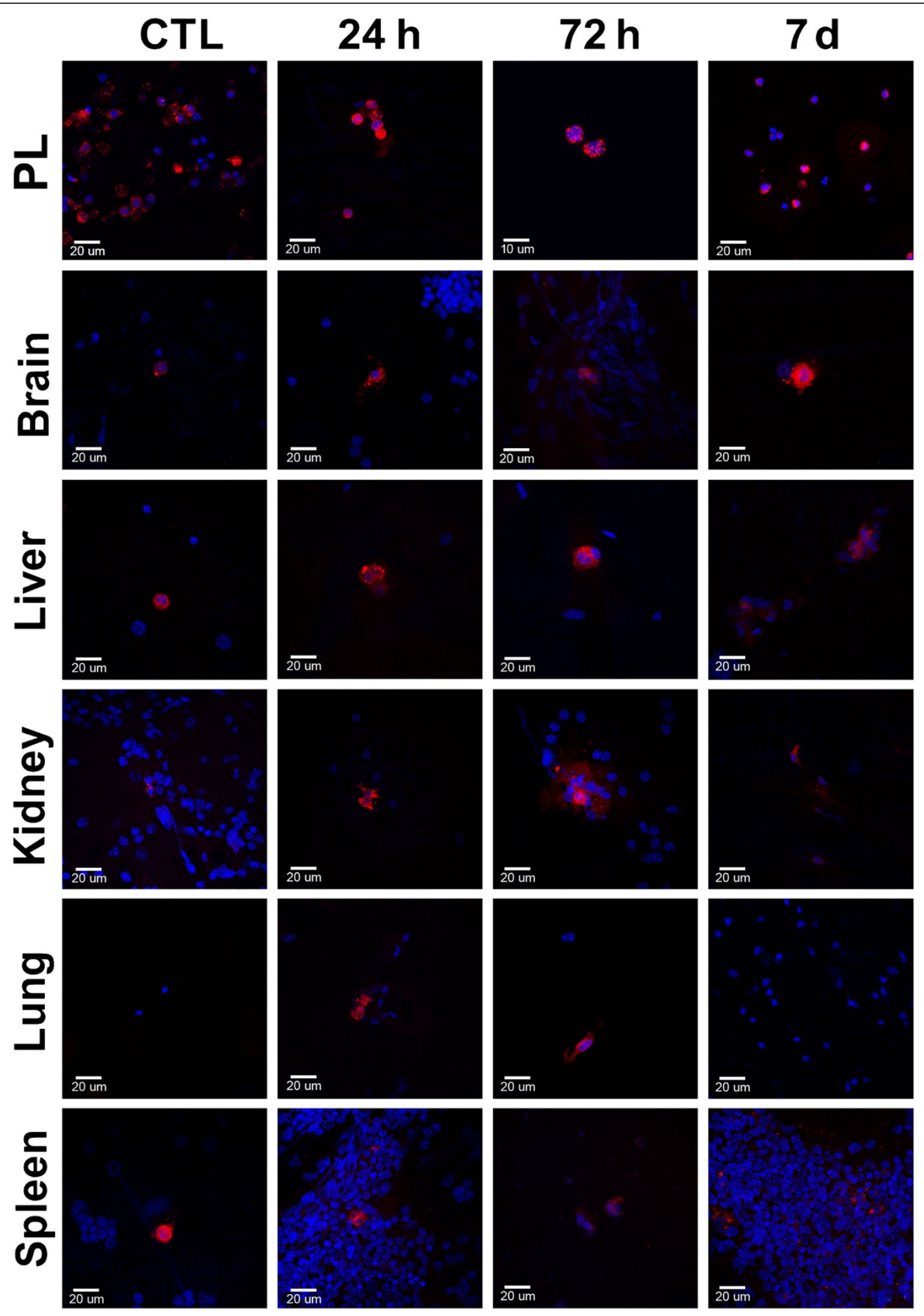

Figure 2 Trafficking of peritoneal cells during systemic candidiasis. Male Swiss mice were previously inoculated by intraperitoneal route with the fluorescent dye PKH-26 PCL and after 24 hours, the mice were intravenously challenged with $5 \times 10^{6}$ C. albicans. After 24 and 48 hours and 7 days, the mice were euthanized and samples of peritoneal cells, brain, liver, kidney, lung and spleen were subjected to fluorescence analysis. PKH-26 PCL: red; DAPI: blue. 
macrophages and neutrophils. Several studies have used PKH-26 PCL for selective tracing of peritoneal phagocytes without staining phagocytes from other tissues or blood stream [24-27]. We previously performed some experiments to evaluate the PHK-26 PCL staining in frozen tissue sections and we observed more artifacts and lower fluorescence intensity than in fresh samples obtained from imprinting techniques (data not shown).

In the present study, $\mathrm{PKH}^{+}$cells were observed in the peritoneum, kidney, spleen and liver samples (Figure 2) from all groups, including the group of non-infected animals ( $\mathrm{HH}$ and CTL groups). In the $\mathrm{HH}-\mathrm{Ca}$ and $\mathrm{Ca}$ groups, $\mathrm{PKH}^{+}$cells were also found both in the lung and brain. In the $\mathrm{HH}$ group, we observed no $\mathrm{PKH}+$ cells in the brain and in the CTL group, no $\mathrm{PKH}+$ cells in the lung. The cellular adoptive transfer assay confirmed the migration of $\mathrm{PKH}^{+}$cells from the peritoneal cavity to all of the infected tissues at all of the time points analyzed in the present study (data not shown).

Furthermore, we observed morphological heterogeneity among migratory labeled cells (Figure 2).

\section{Discussion}

The murine model for disseminated infection by $C$. albicans has been well characterized [28-30]. When fungal cells are intravenously inoculated by lateral tail vein, the fungus spreads rapidly, mimicking the infection that occurs when fungal cells enter the blood stream through the gastrointestinal tract, or an intravenous catheter. In our infected-mice, as previously described in non-progressive Candida hematogenous infection, the infection is controlled in the majority of the tissues, including the liver, spleen, heart and lungs but advances in the kidney and brain $[30,31]$. Here, we have amplified these findings using $\mathrm{HH}$ mice induced by alloxan. The choice of alloxan-induced $\mathrm{HH}$ mice has two rationales. The first one is due to DM represent an important import underlying disease in episodes of candidemia (13$21 \%$ ) [1-3], and the second is because this condition interferes in the animal defense mechanisms, therefore making possible the study of the immunological alterations involved in the infections which undertake the patients with DM. In addition, the alloxan model, when used in the first hours after drug inoculation, mimics only the $\mathrm{HH}$ condition of DM and not the chronic disturbs; as a consequence, the data interpretation is specific to this abnormality. Our data has demonstrated an increase in the fungal load in the tissues of $\mathrm{HH}$-mice (particularly the liver) 7 days after the inoculation. A larger fungal load has also been observed in the tissues of diabetic mice Mosci et al. [4], with an increased load which has been particularly prevalent in the liver of the $\mathrm{HH}$-mice. The data reinforces the idea that the $\mathrm{HH}$ condition increases susceptibility to systemic candidiasis and suggests that this model could be an interesting option for investigating different aspects of this infection.

Several studies have shown that macrophages in a microenvironment rich in glucose exhibit diverse functional alterations, such as increased oxidative stress and enhanced transcription genes encoding for cytokines, growth factors and adhesive molecules [32]. These alterations have been triggered by increased formation of the advanced glycation end products (AGEs) [33]. Considering that the hyperglycemia affects the metabolism of these cells, we have come to the idea that other cellular alterations could be occurring which could affect the migration of these cells. We have identified an enhance in the spread of migratory peritoneal phagocytes during systemic candidiasis in naïve mice and that the $\mathrm{HH}$ condition did not interfere in this process. For this identification we have used the imprinting technique associated with PKH-26 PCL. The analysis of the peritoneal cell migration is not limited to these two methods. The PKH is an extensively used supply for cell tracking protocols $[26,27,34]$, which could be used associated with other methodologies such as flow cytometry and two-photon excitation microscopy. The use of transgenic mouse line with fluorescent protein-labeled is another sophisticated methodology [35]. The imprinting is a simple methodology, routinely used for diagnostic in other situations, as in the evaluation of sentinel lymph nodes for lobular carcinoma of the breast cancer [36]. Several studies have demonstrated that the imprinting is superior to freezing, particularly in cases where the preservation of the tissue structure is not required [37-40]. Here, we have observed that imprinting provides a higher-quality analysis of a larger number of cells than the cryogenic sectioning and it is an interesting option for screening cell trafficking due to an easily and faster methodology.

\section{Conclusions}

In summary, our results reinforce the migratory capacity of the peritoneal cells and demonstrate that the $\mathrm{HH}$ condition does not alter this process, enabling the use of the peritoneal cavity in immunotherapeutic approaches. Immunotherapy from this site has been considered a viable and promising alternative. This route has been used to immunize mice with ex vivo-treated dendritic cells for prostate cancer intervention [41]. Experimentally, ConA has been used to stimulate the peritoneal cell [12]; they have observed increased survival rate during lethal $C$. albicans hematogenous infection. Thus, even in patients with DM, the peritoneal cavity can be used for immunotherapeutic intervention, i.e., as a site for stimulating and macrophages to migrate from the peritoneum to the compromised tissues and to modulate the infectious process. 


\section{Abbreviations}

DM: Diabetes mellitus; HH: Hypoinsulinemic-hyperglycemic; COBEA: Brazilian college of animal experimentation; Group Ca: C. albicans-infected mice; $\mathrm{HH}$-Ca: $\mathrm{HH}$-induced and C. albicans-infected mice; Group HH: HH-induced mice; Control Group (CTL): Free HH-induced and non-infected mice; SSS: Sterile saline solution; PL: Peritoneal lavage; PBS: Phosphate buffered saline; CFU: Colony forming units.

\section{Competing interests}

The authors declare that they have no competing interests.

\section{Authors' contributions}

TFCFS and JV performed the laboratory assays, participated in the sequence alignment, and drafted the manuscript. MSPA conceived the study, participated in its design and coordination, and helped to draft the manuscript. All authors read and approved the final manuscript.

\section{Acknowledgments}

We would like to thank Professor Cristina Pacheco Soares PhD (UNIVAP - Univ do Vale do Paraíba) for presenting the PKH-26 to us and Professor Fábio Porto Foresti PhD (UNESP - Univ Estadual Paulista) for helping us with the fluorescent microscopy. Also, we are grateful to FAPESP for financial support (2009/50818-4; 2009/50654-1).

\section{Author details}

${ }^{1}$ Faculdade de Ciências, Bauru, Departamento de Ciências Biológicas, Laboratório de Imunopatologia Experimental (LIPE), UNESP - Univ Estadual Paulista, Bauru, SP 17033-360, Brazil. ${ }^{2}$ Instituto de Biociências, UNESP - Univ Estadual Paulista, Botucatu 18618-970, Brazil. ${ }^{3}$ Faculdade de Medicina de Botucatu, UNESP - Univ Estadual Paulista, Botucatu, SP, Brazil.

Received: 11 September 2012 Accepted: 18 March 2013

Published: 25 March 2013

\section{References}

1. Kao AS, Brandt ME, Pruitt WR, Conn LA, Perkins BA, Stephens DS, Baughman WS, Reingold AL, Rothrock GA, Pfaller MA, Pinner RW, Haijeh RA: The epidemiology of candidemia in two United States cities: results of a population-based active surveillance. Clin Infect Dis 1999, 29:1164-1170.

2. Nucci M, Colombo AL: Candidemia due to Candida tropicalis: clinical, epidemiologic, and microbiologic characteristics of 188 episodes occurring in tertiary care hospitals. Diagn Microbiol Infect Dis 2007, 58:77-82.

3. Colombo AL, Garnica M, Aranha Camargo LF, Da Cunha CA, Bandeira AC, Borghi D, Campos T, Senna AL, Valias Didier ME, Dias VC, Nucci M: Candida glabrata: an emerging pathogen in Brazilian tertiary care hospitals. Med Mycol 2013, 51:38-44

4. Mosci P, Vecchiarelli A, Cenci E, Puliti M, Bistoni F: Low-dose streptozotocin-induced diabetes in mice. I. Course of Candida albicans infection. Cell Immunol 1993, 150:27-35.

5. Mencacci A, Romani L, Mosci P, Cenci E, Tonnetti L, Vecchiarelli A, Bistoni F: Low-dose streptozotocin-induced diabetes in mice. II. Susceptibility to Candida albicans infection correlates with the induction of a biased Th2-like antifungal response. Cell Immunol 1993, 150:36-44.

6. Fidel PL Jr, Cutright JL, Tait L, Sobel JD: A murine model of Candida glabrata vaginitis. J Infect Dis 1996, 173:425-431.

7. Coleman DC, Bennett DE, Sullivan DJ, Gallagher PJ, Henman MC, Shanley DB, Russell RJ: Oral Candida in HIV infection and AIDS: new perspectives/ new approaches. Crit Rev Microbiol 1993, 19:61-82.

8. Lilic D, Haynes K: Immunity to Specific Pathogens: Candida. In Immunology of Fungal Infections, Volume 1. 1st edition. Edited by Brown GD, Netea MG. Dordrecht: Spinger; 2007:359-380.

9. Pfaller MA, Diekema DJ: Epidemiology of invasive mycoses in North America. Crit Rev Microbiol 2010, 36:1-53.

10. Vazquez-Torres A, Jones-Carson J, Wagner RD, Warner T, Balish E: Early resistance of interleukin-10 knockout mice to acute systemic candidiasis. Infect Immun 1999, 67:670-674.

11. Roilides E, Farmaki E, Evdoridou J, Dotis J, Hatziioannidis E, Tsivitanidou M, Bibashi E, Filioti I, Sofianou D, Gil-Lamaignere C, Mueller FM, Kremenopoulos G: Neonatal candidiasis: analysis of epidemiology, drug susceptibility, and molecular typing of causative isolates. Eur $J$ Clin Microbiol Infect Dis 2004, 23:745-750.
12. Conchon-Costa I, Loyola W, Gaziri LC, Custódio LA, Felipe I: Low dose of Concanavalin-A enhances innate immune response and prevents liver injury in mice infected with Candida albicans. FEMS Immunol Med Microbiol 2007, 49:330-336.

13. Geraldino TH, De Vito E, Custódio LA, Conchon-Costa I, Gaziri LC, Felipe I, Loyola W, Bonifácio KL: Increased tumour necrosis factor-alpha production, higher mannose receptor activity and ability to kill Candida by concanavalin-A-activated macrophages. FEMS Immunol Med Microbiol 2010, 59:11-17.

14. Bellingan GJ, Caldwell H, Howie SE, Dransfield I, Haslett C: In vivo fate of the inflammatory macrophage during the resolution of inflammation: inflammatory macrophages do not die locally, but emigrate to the draining lymph nodes. J Immunol 1996, 157:2577-2585.

15. Almeida SR, Aroeira LS, Frymuller E, Dias MA, Bogsan CS, Lopes JD, Mariano M: Mouse B-1 cell-derived mononuclear phagocyte, a novel cellular component of acute non-specific inflammatory exudate. Int Immunol 2001, 13:1193-1201.

16. Russo RT, Mariano M: B-1 cell protective role in murine primary Mycobacterium bovis bacillus Calmette-Guerin infection. Immunobiology 2010, 215:1005-1014.

17. Ishii M, Kato C, Hakamata A, Kojima N: Targeting with oligomannosecoated liposomes promotes maturation and splenic trafficking of dendritic cells in the peritoneal cavity. Int Immunopharmacol 2011, 11:164-171.

18. Bhaumik S, Mitra R, Varalakshmi C, Khar A: Activated macrophages migrate to the subcutaneous tumor site via the peritoneum: a novel route of cell trafficking. Exp Cell Res 2001, 266:44-52.

19. Oh DY, Morinaga H, Talukdar S, Bae EJ, Olefsky JM: Increased macrophage migration into adipose tissue in obese mice. Diabetes 2012, 61:346-354.

20. Huang F, Wu W: Antidiabetic effect of a new peptide from Squalus mitsukurii liver (S-8300) in alloxan-diabetes. Clin Exp Pharmacol Physiol 2005, 32:521-525.

21. Venturini J, De Camargo MR, Félix MC, Vilani-Moreno FR, De Arruda MS: Influence of tumour condition on the macrophage activity in Candida albicans infection. Scand J Immunol 2009, 70:10-17.

22. Norman GR, Streiner DL: Biostatistics: the Bare Essentials. St. Louis: MosbyYear Book; 1994

23. Skeen MJ, Freeman MM, Ziegler HK: Changes in peritoneal myeloid populations and their proinflammatory cytokine expression during infection with Listeria monocytogenes are altered in the absence of gamma/delta T cells. J Leukoc Biol 2004, 76:104-115.

24. Bellingan GJ, Xu P, Cooksley H, Cauldwell H, Shock A, Bottoms S, Haslett C, Mutsaers SE, Laurent GJ: Adhesion molecule-dependent mechanisms regulate the rate of macrophage clearance during the resolution of peritoneal inflammation. J Exp Med 2002, 196:1515-1521.

25. Satoh T, Saika T, Ebara S, Kusaka N, Timme TL, Yang G, Wang J, Mouraviev V, Cao G, Fattah el MA, Thompson TC: Macrophages transduced with an adenoviral vector expressing interleukin 12 suppress tumor growth and metastasis in a preclinical metastatic prostate cancer model. Cancer 2003, 63:7853-7860.

26. Rajakariar R, Hilliard M, Lawrence T, Trivedi S, Colville-Nash P, Bellingan G, Fitzgerald D, Yaqoob MM, Gilroy DW: Hematopoietic prostaglandin D2 synthase controls the onset and resolution of acute inflammation through PGD2 and 15-deoxyDelta12 14 PGJ2. Proc Natl Acad Sci USA 2007, 104:20979-20984.

27. Bystrom J, Evans I, Newson J, Stables M, Toor I, Van Rooijen N, Crawford M, Colville-Nash P, Farrow S, Gilroy DW: Resolution-phase macrophages possess a unique inflammatory phenotype that is controlled by CAMP. Blood 2008, 112:4117-4127.

28. Louria DB: Brayton RG; Finkel G: Studies on the pathogenesis of experimental Candida albicans infections in mice. Med Mycol 1963 2:271-283

29. Papadimitriou JM, Ashman RB: The pathogenesis of acute systemic candidiasis in a susceptible inbred mouse strain. J Pathol 1986, 150:257-265.

30. MacCallum DM, Odds FC: Temporal events in the intravenous challenge model for experimental Candida albicans infections in female mice. Mycoses 2005, 48:151-161.

31. Lionakis MS, Lim JK, Lee CC, Murphy PM: Organ-specific innate immune responses in a mouse model of invasive candidiasis. J Innate Immun 2011, 3:180-199. 
32. Wautier MP, Chappey O, Corda S, Stern DM, Schmidt AM, Wautier JL: Activation of NADPH oxidase by AGE links oxidant stress to altered gene expression via RAGE. Am J Physiol Endocrinol Metab 2001, 280:e685-e694.

33. Bierhaus A, Nawroth PP: Multiple levels of regulation determine the role of the receptor for AGE (RAGE) as common soil in inflammation, immune responses and diabetes mellitus and its complications. Diabetologia 2009, 52:2251-2263.

34. Donega V, Van Velthoven CT, Nijboer CH, Van Bel F, Kas MJ, Kavelaars A, Heijnen CJ: Intranasal mesenchymal stem cell treatment for neonatal brain damage: long-term cognitive and sensorimotor improvement. PLOS One 2013, 8:e51253.

35. Dong J, Dai XL, Lu ZH, Fei XF, Chen H, Zhang QB, Zhao YD, Wang ZM, Wang AD, Lan Q, Huang Q: Incubation and application of transgenic green fluorescent nude mice in visualization studies on glioma tissue remodeling. Chin Med J (Engl) 2012, 125:4349-4354.

36. Howard-McNatt M, Geisinger KR, Stewart JH 4th, Shen P, Levine EA: Is intraoperative imprint cytology evaluation still feasible for the evaluation of sentinel lymph nodes for lobular carcinoma of the breast? Ann Surg Oncol 2012, 19:929-934.

37. Krause JR, Srodes C, Lee RE: Use of the bone marrow imprint in the diagnosis of leukemic reticuloendotheliosis ("hairy cell leukemia"). Am J Clin Pathol 1977, 68:368-371.

38. Motomura K, Inaji H, Komoike Y, Kasugai T, Nagumo S, Noguchi S, Koyama $H$ : Intraoperative sentinel lymph node examination by imprint cytology and frozen sectioning during breast surgery. Br J Surg 2000, 87:597-601.

39. Creager AJ, Geisinger KR, Perrier ND, Shen P, Shaw JA, Young PR, Case D, Levine EA: Intraoperative imprint cytologic evaluation of sentinel lymph nodes for lobular carcinoma of the breast. Ann Surg 2004, 239:61-66.

40. Khanna R, Bhadani S, Khanna S, Pandey M, Kumar M: Touch imprint cytology evaluation of sentinel lymph node in breast cancer. World J Surg 2011, 35:1254-1259.

41. Williams BJ, Bhatia S, Adams LK, Boling S, Carroll JL, Li XL, Rogers DL, Korokhov N, Kovesdi I, Pereboev AV, Curiel DT, Mathis JM: Dendritic cell based PSMA immunotherapy for prostate cancer using a CD40-targeted adenovirus vector. PLoS One 2012, 7:e46981

doi:10.1186/1471-2334-13-147

Cite this article as: Fraga-Silva et al:: Trafficking of phagocytic peritoneal cells in hypoinsulinemic-hyperglycemic mice with systemic candidiasis. BMC Infectious Diseases 2013 13:147.

\section{Submit your next manuscript to BioMed Central and take full advantage of:}

- Convenient online submission

- Thorough peer review

- No space constraints or color figure charges

- Immediate publication on acceptance

- Inclusion in PubMed, CAS, Scopus and Google Scholar

- Research which is freely available for redistribution 